\title{
lodized salt at households and retail shops in a rural community of Northern India
}

\author{
Rahul Srivastava ${ }^{1}$, Kapil Yadav ${ }^{2}$, Ravi P Upadhyay ${ }^{3}$,Vijay Silan', Smita Sinha ${ }^{5}$, Chandrakant S Pandav ${ }^{6}$, \\ Madhu G Karmarkar?
}

${ }^{1,3,4,5}$ Senior Resident, ${ }^{2}$ Assistant Professor, ${ }^{6}$ Professor and Head, Centre for community Medicine, All India Institute of Medical Sciences, New Delhi, India. ${ }^{7}$ Senior Advisor, Indian Coalition for Control of Iodine Deficiency Disorders, New Delhi, India.

\begin{abstract}
Iodine is an essential micronutrient for humans but its deficiency can cause public health problems. The objective of this study was to estimate the consumption of adequately iodized salt on a household level, and to study the availability, procurement, storage, cost, and knowledge regarding iodized salt and iodine deficiency disorders amongst retail shopkeepers from the Ballabgarh block of Haryana in Northern India. This rural area was the location used for a community-based cross-sectional study by simple random sampling. Salt samples were collected from 363 selected households (out of the calculated 400 household samples) and all the retail shops (233) in the study area. Salt was tested using an iodometric titration method at the Indian Coalition for Control of Iodine Deficiency Disorders (ICCIDD) laboratory in New Delhi. Retail shopkeepers were also interviewed regarding their knowledge and practices. Adequately iodized salt ( $=15$ parts per million) was consumed in $65.2 \%$ of the households, while $17.3 \%$, of the residents were consuming salt with no iodine added (0-5ppm). Adequately iodized salt was sold by $76.3 \%$ of the retail establishments, while $12.3 \%$ were selling salt without any added iodine $(0-5 \mathrm{ppm})$. About $84 \%$ of the shopkeepers were aware that they are selling iodized salt. It was reported by $94 \%$ of the retail shopkeepers that iodized salt is necessary for good health but none of them could identify all the iodine deficiency disorders. Effective strategies are required to educate both consumers and suppliers to achieve Universal Salt Iodization at household level.
\end{abstract}

Keywords: Iodine deficiency disorder, Iodized salt, USI, Household coverage, India.

\section{Introduction}

Iodine is an essential micronutrient for humans and is required in a very small amount i.e. $150 \mu \mathrm{g}$ per day. ${ }^{1}$ The only role of iodine in the body, known at present, is for the synthesis of thyroid hormones. The human body contains 15 to $20 \mathrm{mg}$ of iodine of which almost $80 \%$ is in the thyroid gland. According to World Health Organization (WHO), iodine deficiency is still a public health problem in 54 countries. ${ }^{2}$ It is estimated that a total of $36.5 \%$ (285 million) school-age children have an insufficient iodine intake, ranging from $10.1 \%$ in the WHO Region of the Americas to $59.9 \%$ in the European Region. ${ }^{2}$ Extrapolating this prevalence to the general population generated an estimate of nearly two billion individuals with insufficient iodine intake. Iodine intake was more than adequate, or excessive, in 29 countries. Global Total Goiter prevalence (TGP) in the general population was $15.8 \%{ }^{2}$

In India, it is estimated that more than 200 million people are at risk of Iodine deficiency disorders (IDD), while the number of persons suffering from goiter and other iodine

\section{Practice points}

- Iodine is an essential micronutrient for humans but its deficiency can cause public health problems.

- In India, progress has been made towards the coverage of adequately iodized salt at household level; however, the goal of USI is yet to be attained.

- The present study identified that more than $1 / 3^{\text {rd }}$ of the households were consuming salt with low or no iodine and about one-quarter of local retail shops were selling salt with low or no iodine.

- It was also found that knowledge regarding the importance of iodine and iodine deficiency disorders was low among the shopkeepers.

- Effective strategies are required to educate both consumers and suppliers to achieve USI at household level.

deficiency disorder is above 71 million. ${ }^{3}$ Sample surveys have been conducted in 28 States and 7 Union Territories

Correspondence: Dr. Rahul Srivastava, Resident Doctor, Centre for Community Medicine, All India Institute of Medical Sciences, New Delhi - 110029, India. E-mail: drsrivastava.rahul@gmail.com, rahul.sri2001@gmail.com. 
which have revealed that out of 324 districts surveyed so far, 263 districts are IDD endemic i.e. the prevalence of IDD is more than $10 \%{ }^{4}$

Universal Salt Iodization (USI) has been identified as the most cost-effective strategy for the elimination of IDD. ${ }^{5}$ The World Bank reported that cost of iodizing it is extremely low - only about US $\$ 0.05$ per person per year. ${ }^{6}$ In India, USI was adopted as the primary strategy to control IDD in the year 1992 under the National Iodine Deficiency Disorders Control Program (NIDDCP). ${ }^{7}$ It is important to achieve USI so as to meet the Government's revised goal of NIDDCP, that is to reduce the prevalence of iodine deficiency disorders below $10 \%$ in the entire country by 2012 . $^{3}$

A survey conducted by Government of India and UNICEF in 2009 reported the national coverage of adequately iodized salt at the household level to be $71.1 \%$. While, in the rural area it was $66.1 \%{ }^{8}$ In Haryana State, as per NFHS III, the coverage of adequately iodized salt is $55.3 \%$, with an urban coverage of $73.9 \%$, and $46.8 \%$ in the rural population (2005-2006). ${ }^{9}$

Keeping in mind to achieve the goal of NIDDCP through USI, and the fact that no segregate data is available for iodized salt coverage and practices for rural India, the current study was undertaken to estimate the consumption of adequately iodized salt on a household level, and to study the availability, procurement, storage, cost, and knowledge regarding iodized salt and iodine deficiency disorders amongst retail shopkeepers from the Ballabgarh block of Haryana in Northern India.

\section{Materials and Methods}

Study area and study population

A community-based cross-sectional study was conducted in the IFPA (Intensive Field Practice Area) of CRHSP (Comprehensive Rural Health Services Project), Ballabgarh, Haryana in Northern India. CRHSP, Ballabgarh provides services to 28 villages (rural area) through two Primary Health Centers (PHC); PHC Dayalpur and PHC Chhainsa. PHC Dayalpur serves 17 villages through 6 subcenters, covering a total population of 43,688 , while PHC Chhainsa serves 11 villages through 5 sub-centers, covering a total population of 43,365 . The total population of the 28 villages under IFPA of CRHSP Ballabgarh is $87,053 .{ }^{8}$ Two health workers (one male and one female) are posted at each sub-center, while each PHC has two health assistants (one male and one female). Health workers are responsible for providing healthcare facilities in the villages and to report health status and vital statistics to health assistants. Health assistants monitor the functioning of health workers and report the collected information to the Health Management Information System (HMIS), which is maintained at CRHSP, Ballabgarh. HMIS has the vital information and morbidity status of all the individuals residing in the 28 villages. This information is collected and updated during the annual census conducted by the health workers.

\section{Sample size and sampling technique}

Considering the prevalence of consumption of adequately iodized salt in the household to be $50 \%$, absolute precision of $5 \%$, and a confidence interval of $95 \%$, the sample size calculated was 400 for the households. A simple random list of 400 households was generated by HMIS. Salt samples were also collected from all the retail establishments who reported selling edible salt in the study area.

\section{Methodology}

Figure 1 illustrates the methodology of the study. All the shops in the villages of the study area were identified and visited by the health workers of the respective villages. A list of shops that were reported to sell edible salt was prepared. Salt samples (50 grams of cooking salt) were collected by the health workers from the selected households and all the shops in the IFPA in mid 2010. Shopkeepers (owners of the retail establishments) were also interviewed regarding their information on procurement, storage, re-packing and pricing of the salt. A pre-tested questionnaire was used for the interview of the shop keepers.

Salt samples collected from households and shopkeepers were packed in zip lock plastic packs and coded accordingly. These samples were transported to the Indian Coalition for Control of Iodine Deficiency Disorders (ICCIDD) laboratory at the All India Institute of Medical Sciences (AIIMS), New Delhi. The ICCIDD laboratory is the accredited laboratory for iodine estimation in salt and urine in India and has a quality assurance/quality control program. Salt samples were analyzed for iodine content in the ICCIDD laboratory by the iodometric titration method (gold standard method).

\section{Quality assurance (field survey)}

Health workers and health assistants were trained in one of the monthly meetings at the PHC regarding salt sample procurement, packaging and transportation. They were also trained in conducting the interview using a pre-tested questionnaire. A random sub-sample of 5\% from the selected 400 households was also generated by HMIS. Health assistants again collected 50 grams of salt samples from these listed households. Similarly, salt samples were also collected from $5 \%$ of the retail shops. These samples were transported to the ICCIDD laboratory, while maintaining all the precautions for preventing iodine loss. The results of the two surveys were tabulated and compared. For laboratory analysis all samples were analyzed in duplicate. Laboratory personals at the ICCIDD laboratory were blind regarding the salt samples, since special codes were used to label the salt samples.

\section{Quality assurance (laboratory)}

It was ensured that the process/system used by laboratory to estimate salt iodine content were consistent and operated with a specified level of confidence. Protocol for salt iodine estimation including the Levy Jennings plot was followed. 
Figure 1: Study methodology

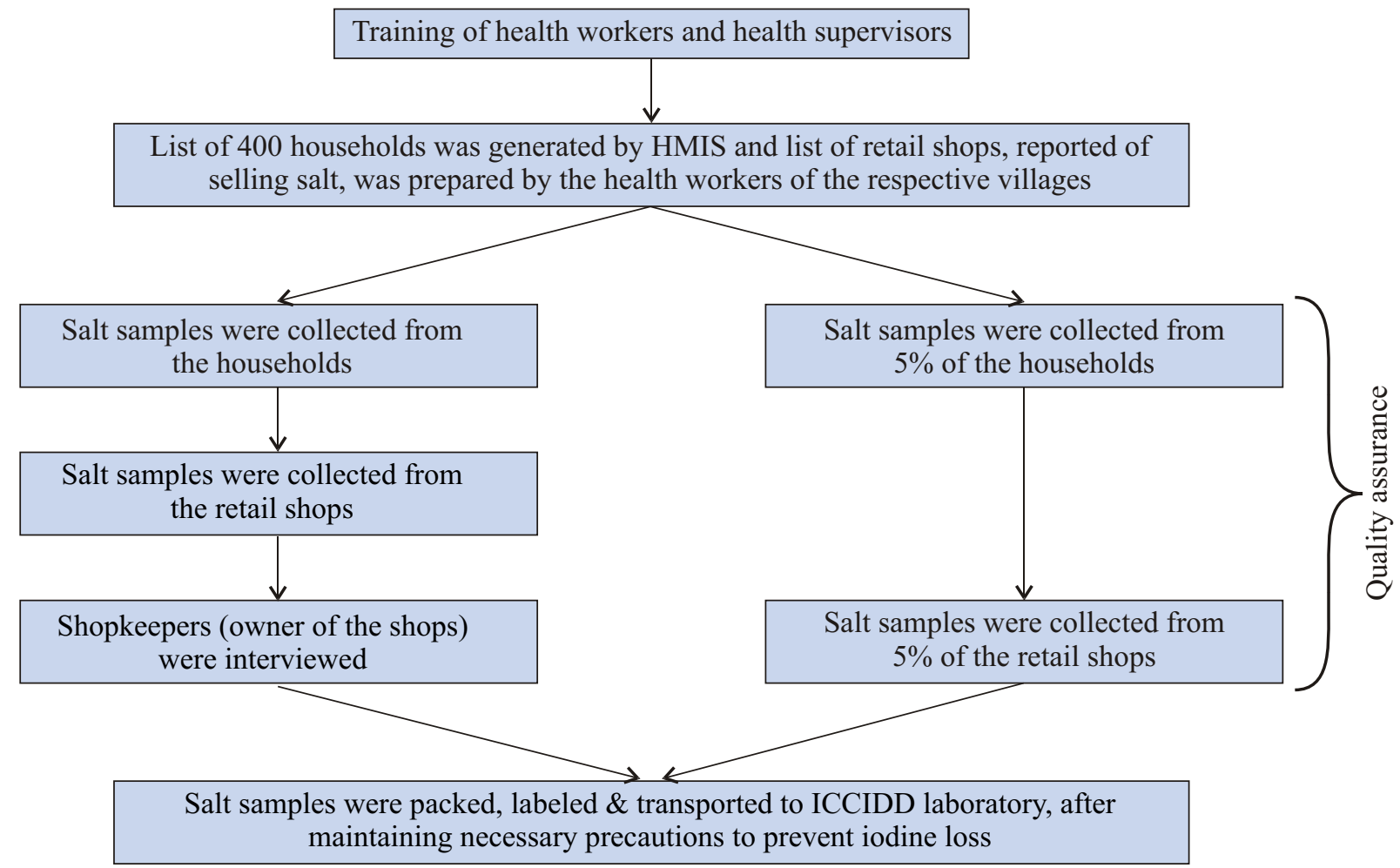

Ethical Issues

All the participants were informed of the purpose and methodology of the study. Written consent was taken from the participants and confidentiality was maintained with their personal information and their participation.

\section{Results}

A total of 363 household salt samples were collected from the 28 villages of the IFPA of CRHSP, Ballabgarh. Out of the target sample size of 201 and 199 households in the villages of PHC Dayalpur and PHC Chhainsa area (generated by HMIS), salt samples could be collected from 180 and 183 households respectively. A total of 37 sampled households in the study area were found locked on two subsequent visits, and hence salt samples could not be collected from them. Therefore, salt samples were collected from $90.1 \%$ of the selected households.

\section{Household iodized salt coverage}

Iodine content of $0 \mathrm{ppm}$ was found in $13.2 \%$ of the household, while $4.1 \%$ and $17.4 \%$ of the households were consuming salt with $1-5 \mathrm{ppm}$ and $6-15 \mathrm{ppm}$ respectively (Table 1 ). Remaining $65.2 \%$ of the households were consuming iodized salt with iodine content of more than $15 \mathrm{ppm}$ (adequately iodized salt).

Table 1: Iodine content of salt at household and retail shop level

\begin{tabular}{|c|c|c|c|c|c|c|}
\hline \multirow{2}{*}{ Iodine content } & \multicolumn{3}{|c|}{ Household level } & \multicolumn{3}{c|}{ Retail shopkeeper level } \\
\cline { 2 - 7 } & $\begin{array}{c}\text { IFPA under PHC } \\
\text { Dayalpur (\%) }\end{array}$ & $\begin{array}{c}\text { IFPA under PHC } \\
\text { Chhainsa (\%) }\end{array}$ & $\begin{array}{c}\text { IFPA under } \\
\text { CRHSP } \\
\text { Ballabgarh (\%) }\end{array}$ & $\begin{array}{c}\text { IFPA under PHC } \\
\text { Dayalpur (\%) }\end{array}$ & $\begin{array}{c}\text { IFPA under PHC } \\
\text { Chhainsa (\%) }\end{array}$ & $\begin{array}{c}\text { IFPA under } \\
\text { CRHSP } \\
\text { Ballabgarh (\%) }\end{array}$ \\
\hline $\mathbf{0 ~ p p m ~}$ & $20(11.1)$ & $28(15.3)$ & $48(13.2)$ & $14(9.0)$ & $9(12.7)$ & $23(10.1)$ \\
\hline $\mathbf{1 - 5} \mathbf{~ p p m}$ & $7(3.9)$ & $8(4.4)$ & $15(4.1)$ & $5(3.2)$ & $0(0)$ & $5(2.2)$ \\
\hline $\mathbf{6 - 1 5} \mathbf{~ p p m}$ & $31(17.2)$ & $32(17.5)$ & $63(17.4)$ & $18(11.5)$ & $8(11.3)$ & $26(11.5)$ \\
\hline $\mathbf{1 6 - 3 0} \mathbf{~ p p m}$ & $76(42.2)$ & $69(37.7)$ & $145(39.9)$ & $48(30.8)$ & $25(35.2)$ & $73(32.2)$ \\
\hline$>\mathbf{3 0} \mathbf{~ p p m}$ & $46(25.6)$ & $46(25.1)$ & $92(25.3)$ & $71(45.5)$ & $29(40.9)$ & $100(44.1)$ \\
\hline Total (n) & $\mathbf{1 8 0}$ & $\mathbf{1 8 3}$ & $\mathbf{3 6 3}$ & $\mathbf{1 5 6}$ & $\mathbf{7 1}$ & $\mathbf{2 7 7}$ \\
\hline
\end{tabular}

Key: IFPA: Intensive Field Practice Area; PHC: Primary Health Centre; PPM: Parts per million. 
Only three households were consuming iodized salt with more than 50ppm iodine. Almost similar distribution of iodine content of salt was found in the villages allocated under the two primary health centers of Dayalpur and Chhainsa $(\mathrm{p}>0.05)$.

\section{Iodized salt at retail shops}

Total of 233 retail shops were present in the IFPA of CRHSP, Ballabgarh. Most of the shops were present in the PHC Dayalpur villages (67\%), while villages under PHC Chhainsa had $33 \%$ retail shops. A total of 227 salt samples were collected and analysed, remaining 6 shopkeepers refused to give salt samples. Iodine content of $0 \mathrm{ppm}$ was found in $10.1 \%$ of the samples collected from the retail shops, while $2.2 \%$ and $11.5 \%$ of the retail shops were selling salt with $1-5 \mathrm{ppm}$ and $6-15 \mathrm{ppm}$ respectively (Table 1 ). Remaining $76.2 \%$ of the retail shops were selling iodized salt with iodine content of more than $15 \mathrm{ppm}$. Eight retail shops were selling iodized salt with more than 50ppm iodine in it. Almost similar distribution of iodine content of salt sold by the retailers, were found among the villages allocated under the two primary health centers of Dayalpur and Chhainsa $(\mathrm{p}>0.05)$.

\section{Availability, procurement, storage and cost of edible salt at the retail shops \\ Total of 233 shopkeepers were interviewed (156 in IFPA under PHC Dayalpur and 77 shops in the IFPA under PHC Chhainsa). Among the interviewed shopkeepers, 84\% (196) of the shopkeepers were aware that they are selling iodized salt, while $15 \%$ of the shopkeepers were not sure about the type of salt they were selling (iodized or non-iodized) and only $1 \%$ (3) shopkeepers reported that they were selling non-iodized salt.}

Regarding procurement of the salt, $87 \%$ of the shopkeepers were procuring salt from a larger market situated in the nearby small town of Ballabgarh (Central market). Nine percent of the shopkeepers were procuring salt from Delhi, while the remaining $4 \%$ were procuring salt in small quantities from other retail shops. Salt was purchased once a month by $48 \%$ of the shopkeepers, while the frequency of salt purchase was more than once in a month in the remaining $52 \%$ of the shops. More than half (61\%) of the shopkeepers were buying salt in large quantities, i.e. one or more katta (50 packets of $1 \mathrm{~kg}$ salt packet in a jute bag and sealed) at a time. Remaining $39 \%$ of the shops were purchasing open $1 \mathrm{~kg}$ packets. Statistically significant association was found between the distance of the retail shop from the whole sale market and the frequency and quantity of salt purchase $(\mathrm{p}<0.01)$.

Salt was purchased by the $71 \%$ of the retailers from the wholesalers on cash payment of the money, while $12 \%$ purchased on credit. Remaining $17 \%$ of the retail shopkeepers purchased salt either on debit or credit, depending upon their economic strength during the time of purchase. Separate place for storage of salt (store room) was not present in $92.7 \%$ of the retail shops. Salt packets ( $k a t t a$ : $10 \mathrm{~kg}$ packet or $1 \mathrm{~kg}$ packet) were kept inside the shop on cupboards, wracks or on the ground. Separate space for salt storage was prepared by $7.3 \%$ (17) retailers. These retailers kept katta in the store room while one kg packets were kept in the shop. Stored salt was brought to the shop as and when required. Cost of the salt ranged from INR7 to INR15 (US\$0.15 to US\$0.32) per $\mathrm{kg}$ with the mean cost of INR10 (US\$0.22) per kg.

Branded salt (company names: TATA, Captain Cook, Shudh, Nirma) was sold by $81.1 \%$ of the retailers. Both, branded/packed salt as well as loose salt, were sold by $18 \%$ of the retailers. Two of the retailers were selling only loose salts. As reported by $69 \%$ of the retailers, iodized salt had maximum sale because of the demand from the community, $20 \%$ of the retailers were selling iodized salt because they considered it to be good for health. Fourteen retailers were selling iodized salt because of promotion/incentive offers, while 12 retailers were selling iodized salt because it was easy to store.

\section{Knowledge of retail shopkeepers about IDD and iodized salt}

It was reported by $94 \%$ of the retail shopkeepers that only iodized salt should be consumed by humans. Four percent were not sure and the remaining two percent reported that iodized salt is not necessary for human consumption. Among those who reported that only iodized salt should be consumed by humans [94\% (219) retail shop keepers], 67\% agreed that iodized salt is necessary for good health. Among $67 \%$ who reported that iodized salt is necessary for good health, none of them could identify all the iodine deficiency disorders listed to them (cretinism, goiter, physical development, and intelligence/mental/cognitive impairment). Goiter was identified by $34 \%$ and impaired intelligence and mental function was identified by $28 \%$ of the retailers as the cause of iodine deficiency. Five retailers, who reported that iodized salt is not necessary for human consumption, only one reported that since iodized salt is costly it should not be consumed by the humans. Remaining four retailers did not answer the question.

Source of knowledge regarding iodized salt was mainly the newspapers $(51 \%)$ and television $(46 \%)$ followed by the shopkeepers $(21 \%)$, neighbors $(18 \%)$ and radio $(18 \%)$. None of the retailers reported health providers or posters/banners being the source of knowledge regarding iodized salt.

\section{Discussion}

The studies showed that two-third (65.2\%) of the households were consuming adequately iodized salt, while about one-fifth (21.5\%) of the households were consuming inadequately iodized salt. Nearly $14 \%$ of the households were consuming salt with nil iodine. These results were in concordance with a survey (Coverage Evaluation Survey 2009) conducted by UNICEF in India, ${ }^{9}$ which reported the 
coverage of adequately iodized salt in the household level to be $66.1 \%$ in rural India, while in the state of Haryana it was $86.7 \%$. Another national level survey in 2005-06 (NFHS III) ${ }^{10}$ reported the coverage of adequately iodized salt to be $41.2 \%$ in rural India, while $55 \%$ coverage was found in the state of Haryana. Iodine was estimated by using spot testing kits in these national level surveys, while in the present study, iodine estimation was done by iodometric titration method which is considered to be the gold standard for iodine estimation. ${ }^{1,11}$ Srinath $^{12}$ reported the coverage of adequately iodized salt to be $64 \%$ in urban and rural areas of Ballabgarh. Consumption of adequately iodized salt has certainly increased over the years, but the goal of universal salt iodisation (USI), still needs to be achieved.

Almost $3 / 4^{\text {th }}$ of the retailers were selling adequately iodized salt. This was slightly higher than the iodized salt coverage at the household level. This decrease in the adequately iodized coverage at the household level might be due to the loss of iodine from the edible salt due to improper storage practices, or may be big retailers are selling the non-iodized salt. Another possible reason could be that the retailers might have given the adequately iodized salt sample to the researchers. More than $12 \%$ of the retailers were selling salt to which no iodine was added (0-5 ppm). Government of India lifted the ban on sale of non-iodized salt in the year 2000 but then again realizing the importance and requirement of iodized salt, Government of India reinstated the ban in the year 2006. ${ }^{13}$ In-spite of the five years of complete ban on sale of non-iodized salt, retailers are still procuring salt which is not containing any iodine or is inadequately iodized. More worryingly, these practices of the existence of non-iodized salt in the market is occurring at a place which is roughly 25 miles from the capital of the country and are having good connectivity with roads and railways.

All most all the retailers were having knowledge regarding the importance of iodized salt but only $2 / 3 \mathrm{rd}$ of them partially knew the consequences of not consuming iodized salt. Retailers were not aware regarding the storage practices of the salt. Distance of the retailers was one of the significant determinant regarding the procurement and amount of salt purchase from the whole sale market.

In order to move swiftly towards the USI goal of more than $90 \%$ consumption of adequately iodized salt at household level, appropriate intervention should be targeted towards the consumer and as well as towards the supplier. Regarding the consumer level, communication for behavior changes $(\mathrm{CBC})^{14}$ should be scaled up. There is a need to undertake strategic communication efforts through media, health system and schools. This would make the community aware of the importance of iodized salt, and thereby creating a demand for iodized salt. The consumers need to realize that these efforts in turn would contribute towards ensuring optimum mental and physical development of the future generation.

\section{Conclusion}

The present study identified that more than one-third of the households were consuming salt with low or no iodine and about one-quarter of local retail shops were selling salt with low or no iodine. Regular community-based awareness activities regarding the benefits of iodized salt can be conducted through Anganwadi workers (community-based front line voluntary workers), auxiliary nurse midwives, nongovernment organizations, self-help groups, and schools. Shopkeepers should also be trained and educated so that they can further increase the awareness and educate the community regarding iodized salt. Implementation of the existing law and effective monitoring system would necessary to ensure the supply and sale of the iodized salt in the community and would help to reduce Iodine-deficiency disorders.

\section{Acknowledgement}

The authors would like to thank the health workers, health assistants and other staff of the primary health centre who helped in the collection of the salt samples.

\section{Conflict of Interest}

None Declared

\section{References}

1. International Council for the Control of Iodine Deficiency Disorders (ICCIDD). Assessment of the iodine deficiency disorders and monitoring their elimination: A guide for programme managers. $2^{\text {nd }}$ Edition. Geneva: ICCIDD, UNICEF and WHO, 2007.

2. Andersson M, Takkouche B, Egli I, Allen HE, de Benoist B. Current global iodine status and progress over the last decade towards the elimination of iodine deficiency. Bull World Health Organ 2005;83:518-25.

3. IDD and Nutrition Cell, National Rural Health Mission (India). Revised policy guidelines on National Iodine Deficiency Disorders. New Delhi: Director General of Health Services, Ministry of Health and Family Welfare, 2006.

4. IDD and Nutrition Cell, National Rural Health Mission (India). National Iodine Deficiency Disorders Control Programme. Annual Report (2008-09). New Delhi: Director General of Health Services, Ministry of Health and Family Welfare, 2009.

5. UNICEF. The State of the World's Children, 2009. Maternal and Newborn Health. New York: United Nations Children's Fund, 2008.

6. McGuire J, Galloway R. Enriching lives: overcoming vitamin and mineral malnutrition in developing countries. Development in Practice Series. Washington DC: World Bank, 1994.

7. IDD and Nutrition Cell, National Rural Health Mission (India). National Iodine Deficiency Disorders. New 
Delhi: Director General of Health Services, Ministry of Health and Family Welfare, 2009.

8. Krishnan A, Nongkynrih B, Yadav K, Singh S, Gupta V. Evaluation of computerized health management information system for primary health care in rural India. BMC Health Serv Res 2010;10:310.

9. UNICEF. Coverage Evaluation Survey 2009. All India Report. New Delhi: United Nations Children's Fund, 2010.

10. International Institute for Population Sciences (IIPS) and Macro International. National Family Health Survey (NFHS-3), 2005-06: India: Volume I. Mumbai: IIPS, 2007.

11. Pandav CS, Arora NK, Krishnan A, Sankar R, Pandav S, Karmarkar MG. Validation of spot-testing kits to determine iodine content in salt. Bull World Health Organ 2000;78:975-80.

12. Srinath SS. Iodine status of pregnant women attending antenatal care clinic at Comprehensive Rural Health Services Project (CRHSP), Ballabgarh, Haryana, North India. [thesis] 2004. New Delhi: Centre for Community Medicine, All India Institute of Medical Sciences, 2004.

13. Department of Health. The Prevention of Food Adulteration Act 1954. Act 37 of 1954. New Delhi: Ministry of Health and Family Welfare, 1954.

14. Favin M, Griffiths M. Communication for Behavior Change in Nutrition Projects. A Guide for World Bank Task Managers. Washington, DC: World Bank, 1999. 